\title{
SIMULATION-BASED APPROACH FOR CALCULATING THE RELIABILITY OF LOGISTIC SUPPORT PROCESS
}

\section{SYMULACYJNY MODEL NIEZAWODNOŚCI PROCESU WSPARCIA LOGISTYCZNEGO}

\author{
Sylwia Werbińska \\ Wroclaw University of Technology, Division of Logistics and Transportation Systems \\ Politechnika Wroclawska, Zakład Logistyki i Systemów Transportowych \\ 50-370 Wroclaw ul. Wybrzeże Wyspiańskiego 27 \\ e-mail: sylwia.werbinska@pwr.wroc.pl
}

\begin{abstract}
Any operational system, in order to successfully accomplish its intended mission, must rely on logistic support that will be available when required. Moreover, in many systems undesired event occurs later than components failure, if and only if repair is not completed within a grace period. Thus, in the paper there is considered the time dependent system of systems where the system total task must be executed during the constrained time resource. There is used the simulation approach to investigate the influence of parameters of the procurement process (order quantity, critical inventory level, lead-time length) and parameters of time resource on the system of systems behavior.
\end{abstract}

Keywords: system availability, logistic support system, procurement process, time dependency,

Streszczenie: Podstawowe zadania systemu eksploatacji obejmuja zapewnienie ciagłości pracy obiektów technicznych. Realizacja tak postawionego celu możliwa jest dzięki funkcjonowaniu niezawodnego systemu wsparcia logistycznego. $Z$ tej perspektywy zdefiniowano model nadsystemu z pojedynczą rezerwą czasowa. $\mathrm{W}$ celu przeprowadzenia analiz wpływu: zawodności procesu zaopatrzenia na wyniki eksploatacji systemu technicznego, poziomu rezerwy czasowej na niezawodność nadsystemu, oraz struktury niezawodnościowej systemu technicznego na poziom funkcjonowania nadsystemu wykorzystano proces symulacji Monte Carlo.

Słowa kluczowe: gotowość, system wsparcia logistycznego, proces zaopatrzenia, rezerwa czasowa 


\section{SIMULATION-BASED APPROACH FOR CALCULATING THE RELIABILITY OF LOGISTIC SUPPORT PROCESS}

\section{Introduction}

The main objective of any operational system is to perform continuously its intended functions. Failure of any working element affects the operational process and adds costs for spare parts, labour and maintenance materials. In addition to the losses on these accounts, there is also a loss of profit margin caused by system downtime.

Sufficient inventory level of spare parts has to be maintained to keep the system in operating condition. When the spare elements are under stocked, it may lead to extended system downtime and, as a consequence, have a negative impact on the system availability level. On the other hand, maintenance of excessive spares can lead to large inventory holding costs. Moreover, the requirements for planning the logistics of spare elements being necessary in maintenance actions of operational systems differ from those of other materials in several ways: the service requirements are higher, the effects of stock-outs may be financially remarkable, the demand for parts may be sporadic and difficult to forecast, and the prices of individual parts may be very high.

There is a plethora of models in the literature on reliability theory regarding to the spares supply process optimization. The surveys $[1,3,4,5,6]$ review the growing body of literature on spare parts inventories problem.

The stock level of spare parts is dependent on the chosen maintenance policy. Therefore, maintenance programs should be designed to reduce both, the maintenance and inventory related costs. As a result, the problems of system performance optimization can be solved by joint, rather than separate or sequential approach to define the maintenance and inventory policies.

Consequently, there is used a "system of systems" conception to model the interactions between operational system and its logistic support system. According to the definition [2], the system of systems context arises when a need or a set of needs are met with a mix of multiple systems, each of which are capable of independent operation but must interact with each other in order to provide a given capability. More information can be found in [7, 9, $11]$. 
According to the present knowledge, the time redundancy is considered as the effective tool for e.g. reliability improvement. In the case of two or more independent systems integration problem, time dependency is a convenient approach used to design the interactions between these systems. For more information see e.g. $[7,8,9,11]$.

\section{Time dependent system of systems describtion}

Consider a repairable system of systems under continuous monitoring, in which there are integrated two independent systems: operational and its supporting system. Both systems have only two states: upstate, when they are operable and can perform its specified functions, and downstate, otherwise.

The system of systems total task is defined as the continuous performing of exploitation process. Moreover, in the presented model the logistic support functions are narrowed down only to providing the necessary spare parts to the operational system. As a result, the logistic support system is inoperable when there is no capability of supplying the operational processes with necessary spares.

The operational system is composed of $M$ identical elements working in a reliability structure, which determines the moments when the system goes to a down-state. Let's also assume that elements' failures are random in time, and each failure entails a random duration of repair before the element/system is put back into service. Let's also assume that any information about failures in this system is reliable and comes immediately to the logistic system.

In the investigated model, when logistic support system is in up-state, the ability of the system of systems depends only on:

- the time, when the operational system is operable,

- the time of technical system repair.

In the situation, when the supporting system is inoperable due to the lack of spare parts, the system of systems availability also depends on the logistic delayed time, which is necessary to solve logistic problems.

Moreover, if there is restricted the system of systems total task completion time, defined as the time of operational system recovery process, the system of systems remains in upstate if this defined time will be shorter than time resource. Otherwise, the system of systems will fail and remain in downstate till the end of delivery process. 
Consequently, the following additional model assumptions are taken into account to define the system of systems performance process:

- randomness and independency of all the performed processes,

- critical inventory level (CIL) used as a stock policy,

- the individual time redundancy used to model the system of systems performance [9].

\section{A simulation model}

To the best author's knowledge, an effective way for achieving the reliable operational systems logistic support especially bases on meeting two targets: reliability/availability and cost constraints:

$$
\left\{\begin{array}{l}
C_{s}=\frac{C_{s j}}{E\left[T_{j}\right]} \\
A \leq A_{\min }
\end{array}\right.
$$

where: $C_{s j}=$ the expected total system of systems costs in a $j$ th procurement cycle, $T_{j}=$ the random time of the $j$ th cycle, $A=$ the system of systems' availability ratio, $A_{\min }=$ the limiting availability ratio of system of systems performance

For the investigated model, the expected total system of systems cost in a $j$ th procurement cycle may be calculated as [11]:

$$
C_{s}=c_{f} H(t)+c_{o}+c_{p} Q+c_{h} E\left[\int_{0}^{T_{j}} I(t) d t\right]+P_{n n j}\left(k_{f} H(t)+c_{d w} E\left[\xi_{1}\right]\right)
$$

where: $c_{f}=$ operational element replacement cost, $c_{o}=$ cost for an order placing, $c_{p}=$ cost of one spare purchasing, $c_{h}=$ holding cost per spare per unit time, $I(t)=$ the quantity on-hand at time $t, P_{n n j}=$ probability that system of systems fails, $k_{f}=$ fixed penalty cost per system failure, $c_{d w}=$ downtime dependent cost per unit time

The analytical model of performance of the presented system of systems with time dependency is investigated in $[8,9,10,11]$.

The analytical results of the modeled problem can be obtained only for a small amount of cases, when the operational system is a single-unit system, the performed processes are modeled according to the exponential 
distributions, etc. (see. [7]). Thus, there can be written the following conclusion, that this analytical model is an oversimplified version of the real system behavior, so the obtained results are not traceable to practical situations.

To overcome this problem, there is proposed a simulation model of time dependent system of systems performance, which has been developed with the use of GNU Octave program. The simulation algorithm of the modeled system of systems is given in Figure 1.

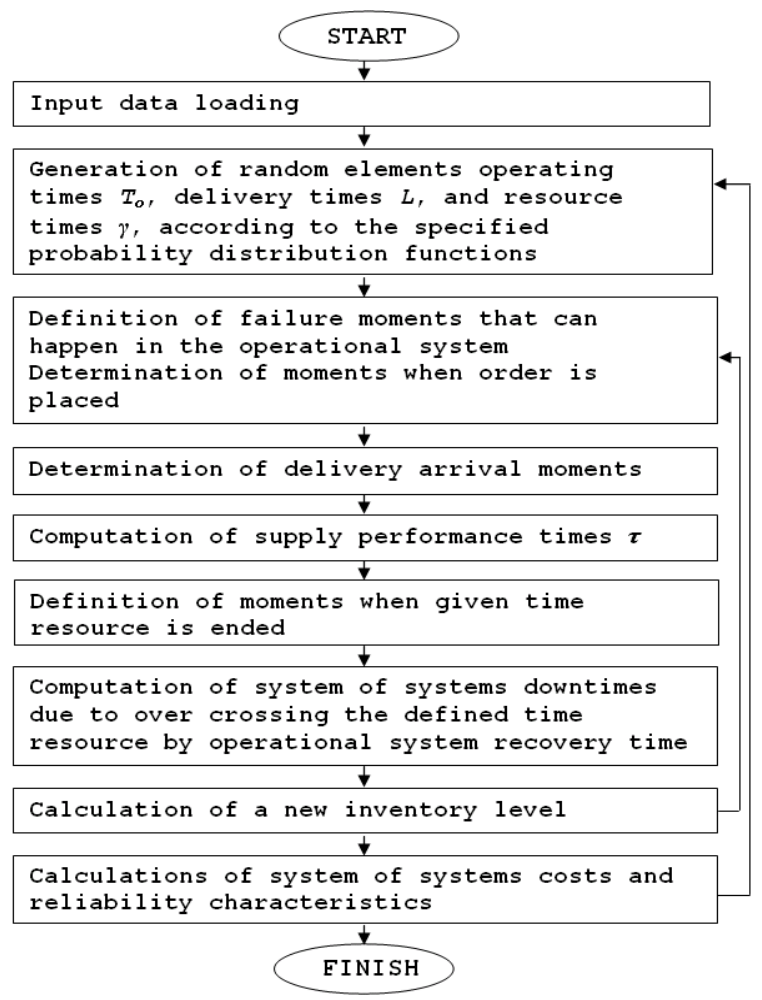

Fig. 1. Simulation algorithm of time dependent system of systems performance

The system of systems level of availability ratio, the probability of system of systems downtime occurrence, or economic results strongly depend on the operational system reliability structure. That is why, the model of time dependent system of systems performance (Fig. 1) was created for the three various system reliability structures - series, parallel and " $k$ out of $n$ ". The simulation results of the modeled system of systems have been carried out for the input parameters, presented in Table 1. 
Table 1. Input parameters of modeled system of systems

\begin{tabular}{|c|c|l|}
\cline { 2 - 3 } \multicolumn{1}{c|}{} & $\begin{array}{c}\text { Initial } \\
\text { value }\end{array}$ & \multicolumn{1}{c|}{ Explanation of denotation } \\
\hline$A_{o}$ & 1 & Weibull's shape parameter of single operational element time to failure \\
\hline $1 / B_{o}$ & 100 & Weibull's scale parameter of single operational element time to failure \\
\hline$A_{r}$ & 1 & $\begin{array}{l}\text { Weibull's shape parameter of single operational element replacement } \\
\text { time }\end{array}$ \\
\hline $1 / B_{r}$ & 10 & $\begin{array}{l}\text { Weibull's scale parameter of single operational element replacement } \\
\text { time }\end{array}$ \\
\hline$A_{L}$ & 1 & Weibull's shape parameter of lead-time time \\
\hline $1 / B_{L}$ & 1000 & Weibull's scale parameter of lead-time time \\
\hline$A_{\gamma}$ & 1 & Weibull's shape parameter of time resource time \\
\hline $1 / B_{\gamma}$ & 10 & Weibull's scale parameter of time resource time \\
\hline$k$ & 1 & "k" out of "M" \\
\hline$M$ & 5 & number of elements working in an operational system \\
\hline$s$ & 5 & critical inventory level \\
\hline$Q$ & 30 & order quantity \\
\hline$c_{w}$ & 50 & replacement cost of a unit \\
\hline$c_{o}$ & 50 & ordering cost \\
\hline$c_{p}$ & 50 & purchase cost of one unit \\
\hline$c_{h}$ & 100 & inventory unit holding cost per unit time \\
\hline$k_{f}$ & 1000 & penalty cost of system of systems failure occurrence \\
\hline$c_{d w}$ & 1000 & cost of system of systems downtime unit \\
\hline
\end{tabular}

\section{Simulation results}

The main reliability and economic results are presented in Figures 2 - 9 .

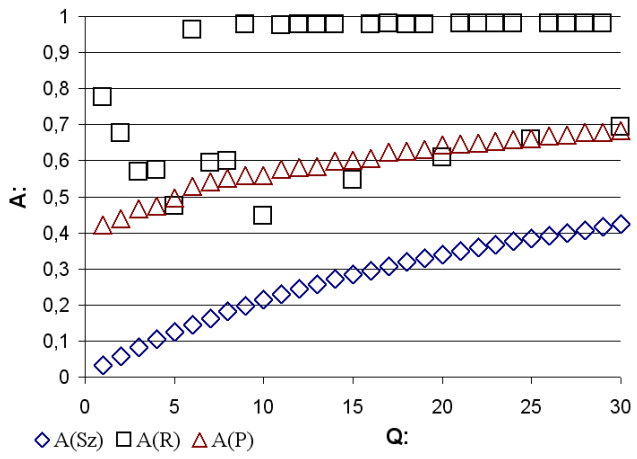

Fig. 2. System of systems availability ratio for various levels of order quantity of spare elements

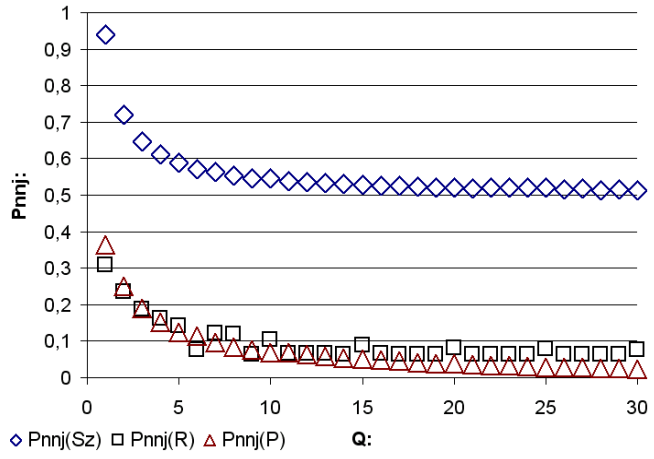

Fig. 3. The system of systems downtime probability for various levels of order quantity of spare elements 


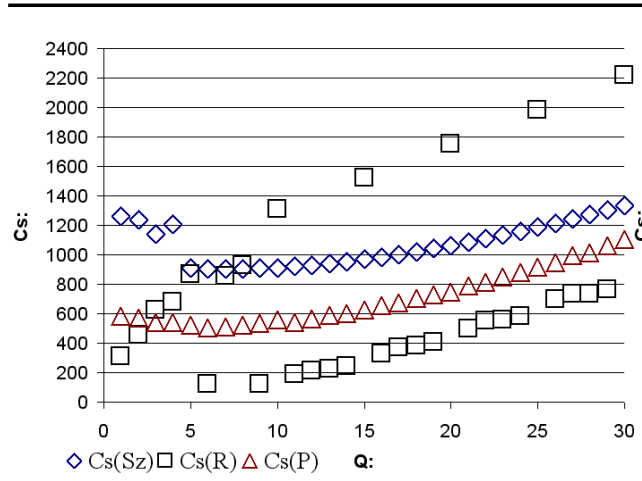

Fig. 4. Expected cost per unit time function for various levels of order quantity of spare elements

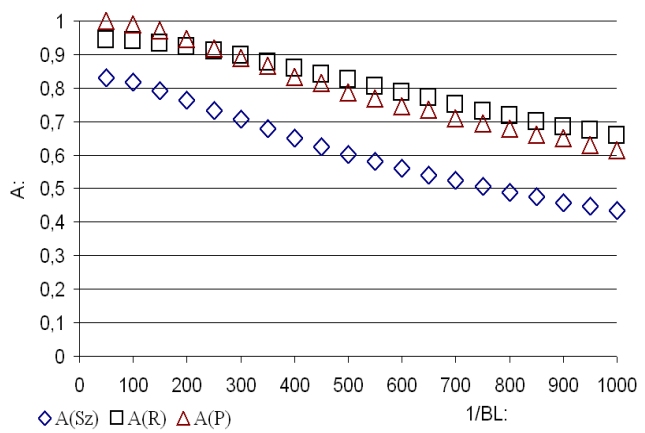

Fig. 6. System of systems availability ratio for various lead-time lengths

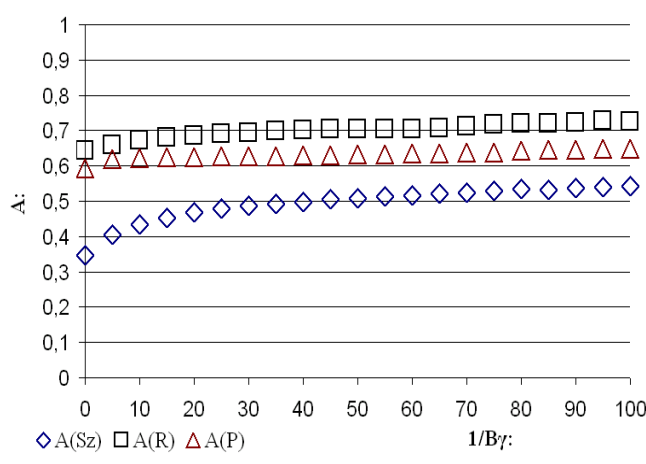

Fig. 8. System of systems availability ratio for various lengths of time resource

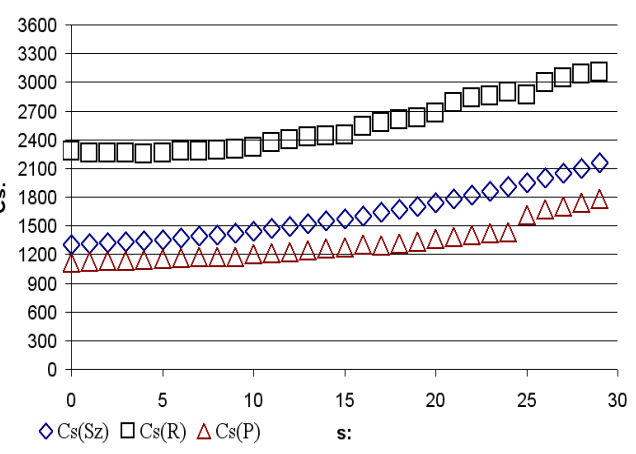

Fig. 5. Expected cost per unit time function for various critical inventory levels

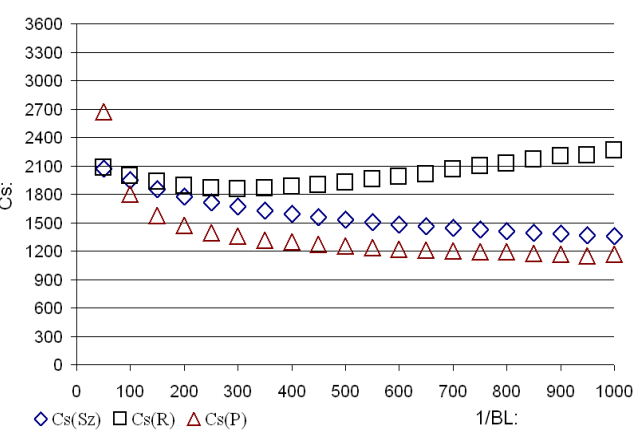

Fig. 7. Expected cost per unit time function for various lead-time lengths

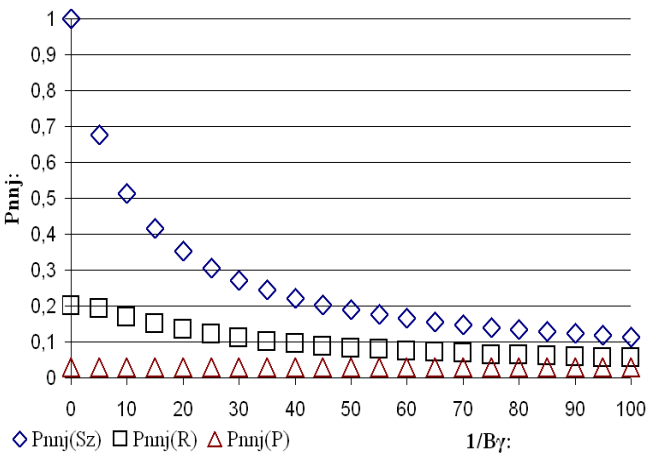

Fig. 9. The system of systems downtime probability for various lengths of time resource 
The ordered and delivered spare parts quantity determines the length of a single procurement cycle (time that elapses between the two consecutive moments when the inventories on-hand drop to a critical level). As a result, the bigger the ordered quantity, the higher mean stock level in the system and rarer deliveries performed.

The expected costs incurred by the system of systems with a differentstructured operational system are mainly determined by the inventory holding costs and system of systems' downtime costs (Fig. 4). When the level of ordered quantity rises, the expected costs function has the local minimum in case of series and $\mathrm{k}$ out of $\mathrm{M}$ systems. It is a result of rarer deliveries and downtimes occurrence that arise from inventory lack. On the other hand, the more spare elements are purchased, the higher inventory holding costs are incurred.

The worst solutions for the system of systems with operational system in parallel occur when the ordered quantity $Q$ is a multiple of $M$. If all $M$ elements are replaced and there is no spares remaining in a logistic system, there is a higher downtime probability and its economical consequences, than if there are some elements in a stock. This downtime costs together with the inventory holding costs have the greatest influence on the system of systems economic results.

The same effect can be seen when availability of system of systems with operational system in parallel is analyzed. The system of systems reaches the lowest availability ratio level when $Q$ is a multiple of $M$. For system of systems with other reliability structures of operational systems, the rarer and bigger deliveries, the higher availability ratio is achieved.

The level of ordered quantity has also the influence on the probability of system of systems downtime occurrence, what is especially evident for a series structure case (Fig. 3). A lower level of ordered quantity forces frequent deliveries, and as a result, there is higher probability that the possible delays of the delivery cause the system of systems downtime.

The next parameter of the procurement process, which affects the system of systems performance, is the critical inventory level (Fig. 5). The higher critical inventory level, the higher the mean inventory level in a system what incurs higher inventory holding costs. However, the higher $s$ level gives also a possibility to reduce the delivery delay consequences what has a positive impact on system of systems reliability results.

Moreover, there also can be seen the influence of lead-time length on the system of systems behavior. The longer lead-time affects especially the reliability characteristic of the system of systems (Fig. 6). On the other hand, the longer the lead-time, the lower inventory holding costs and the 
higher downtime costs incurred, what is connected with the bigger probability of system of systems downtime occurrence. This relation can be seen in a Figure 7 as a local minimum of the $C_{s}$ value.

There is also a question about the relations between the length of time resource and the system of systems reliability characteristics. As might be expected, the shorter time resource makes system of systems less tolerant for any negative events occurrence during the performed processes. As a result, the level of availability ratio decreases (Fig. 8) and the level of system of systems downtime probability increases (Fig. 9).

\section{Conclusions}

For summarizing the above consideration, it has to be noted that the basic decision variables in the presented model are: order quantity and critical inventory level (during the design of logistic support system) and the defined time resource (when designing the system of systems).

In order to model the time dependencies between the operational system and its logistic support system, there have to be identified basic relations, which result from the system of systems structure, components' parameters, or processes' execution times.

In other words, the presented model especially can support decision processes in the area of supply task performance requirements. Especially gives a convenient tool to decide which supplier can provide the desirable time of supply delivery in order to achieve a defined system of systems' operational capability.

On the other side, the developed model can be helpful to assess the reliability requirements of operational system elements in order to provide the continuous system of systems' total task performance

\section{References}

[1] Cho, I.D., Parlar, M.: A survey of maintenance models for multi-unit systems. European Journal of Operational Research 51, 1991.

[2] Crossley, W. A.: System of systems: an introduction of Purdue University Schools of Engineering Signature Area. Available on: http://esd.mit.edu/symposium/pdfs/papers/crossley.pdf (29.11.2006).

[3] Guide Jr, V.D.R., Srivastava, R.: Repairable inventory theory: Models and applications. European Journal of Operational Research Vol. 102/1, 1997. 
[4] Kennedy, W.J., Patterson, J.W., Fredendall, L.D.: An overview of recent literature on spare parts inventories. International Journal of Production Economics Vol. 76, Issue 2, 2002.

[5] Nahmias S.: Approximation techniques for several stochastic inventory model. Computer and Operations Research Vol. 8, No. 3, 1981

[6] Pierskalla, W.P., Voelker, J. A.: A survey of maintenance models: the control and surveillance of deteriorating systems. Naval Research Logistics Quarterly 23, 1976.

[7] Werbińska, S.: Model of logistic support system with time dependency. (in prep.)

[8] Werbińska, S.: Problems of availability maintenance of logistic support system with time dependency (in Polish). Proceedings of Winter School of Reliability. WITE Radom, 2008.

[9] Werbińska, S.: The reliability model of logistic support system with Time Dependency (in Polish). Logistics No. 3, 2007a.

[10] Werbińska, S.: The availability model of logistic support system with time redundancy. Maintenance and Reliability No. 3, 2007b.

[11] Werbińska S.: Problems of designing logistic support system with time dependency. SYSTEMS Journal of Transdisciplinary Systems Science, Vol. 12, No. 2, 2007c

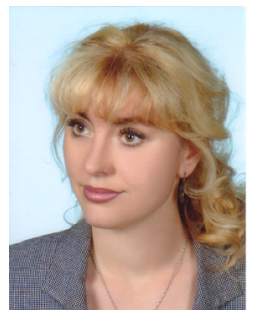

PhD. student Sylwia Werbińska, Wroclaw University of Technology, Division of Logistics and Transportation Systems, interested in: logistics and reliability theory 